\title{
Pengaruh Poliethilen Glikol $60008 \%$ pada Serum Lipemik terhadap Hasil Pemeriksaan Glukosa, SGOT dan SGPT
}

\author{
Mimi Sugiarti, Eka Sulistianingsih \\ Program Studi Teknologi Laboratorium Medis Program Sarjana Terapan Poltekkes Tanjungkarang
}

\begin{abstract}
Abstrak
Setiap laboratorium harus memberikan hasil yang teliti, cepat dan tepat.Dari total kesalahan laboratorium $61 \%$ merupakan kontribusi dari kesalahan pra analitik, kesalahan analitik 25\%, dan kesalahan pasca analitik 14\%. Pra Analitik merupakan tahap persiapan awal, sangat menentukan kualitas sampel yang akan dihasilkan dan proses kerja selanjutnya. Ada dua kelompok pra analitik yaitu pra analitik ekstra laboratorium dan pra analitik intra laboratorium. Proses pra analitik meliputi persiapan pasien, cara dan waktu pengambilan sampel, pengiriman sampel ke laboratorium, penanganan, perlakuan terhadap proses persiapan sampel sampai selesai dikerjakan. Kondisi serum lipemik dapat mengganggu hasil pemeriksaan kimia darah, kususnya pemeriksaan Glukosa, SGOT dan SGPT. Dilakukan preparasi sampel lipemik sebelum pemeriksan parameter tersebut. Preparasi berupa presipitasi menggunakan Poliethilen Glikol (PEG). 6000 8\%. Supernatan digunakan untuk pemeriksaan Glukosa, SGOT dan,SGPT. Tujuan dari penelitian ini untuk mengetahui pengaruh presipitasi menggunakan Poliethylen Glikol pada serum Lipemik terhadap hasil pemeriksaan Glukosa, SGOT dan SGPT. Penelitian dilakukan di Laboratorium Kimia Klinik Jurusan Analis Kesehatan,dengan metode Eksperimen. Sampel lipemik diperiksa sebelum dan sesudah presipitasi menggunakan (PEG) 6000 8\% sejumlah 30 kali pengulangan. Hasil di analisa menggunakan Independent Sampel T test. diperoleh p value sebesar 0,000 berarti ada perbedaan sebelum dan setelah presipitasi dengan PEG 6000.8\%.
\end{abstract}

Kata kunci : Glukosa, Lipemik, Poliethilen Glikol, SGOT, SGPT

\section{Effect of Polyethylene Glycol 6000.8\% in Lipemic Serum on Glucose Examination Results SGOT and SGPT}

\begin{abstract}
Each laboratory must provide accurate, fast and precise results. Of the total laboratory errors, $61 \%$ are contributed by pre-analytical errors, $25 \%$ analytical errors, and $14 \%$ post-analytic errors. Pre-Analytical is the initial preparation stage, it really determines the quality of the sample to be produced and the next work process. There are two pre-analytic groups, namely extra-laboratory pre-analytic and intra-laboratory pre-analytic. The pre-analytic process includes patient preparation, sampling method and time, sample delivery to the laboratory, handling, treatment of the sample preparation process until it is completed. Lipemic serum conditions can interfere with the results of blood chemistry examinations, especially glucose, SGOT and SGPT examinations. Sample preparation is carried out lipemic before examining these parameters. Preparation in the form of precipitation using Polyethylene Glycol (PEG). 6000 8\%. The supernatant was used for examination of Glucose, SGOT and, SGPT. The purpose of this study was to determine the effect of precipitation using Polyethylene Glycol on Lipemic serum on the results of Glucose, SGOT and SGPT examinations. The research was conducted at the Clinical Chemistry Laboratory, Department of Health Analyst, with the experimental method. Lipemic samples were examined before and after precipitation using (PEG) $60008 \%$ with a total of 30 repetitions. The results were analyzed using the Independent Sample T test. The p value of 0.000 means that there is a difference before and after precipitation with PEG $6000.8 \%$.
\end{abstract}

Key words : Glukosa, Lipemik, Poliethilen Glikol ,SGOT,SGPT

Korespondensi : Mimi Sugiarti, Jurusan Teknologi Laboratorium Medis Poltekkes Tanjungkarang, J1.SoekarnoHatta No.1 Hajimena, Bandar Lampung, Mobile 081214886917, e-mail mimizoom123@gmail.com 


\section{Pendahuluan}

Sebagai subsistem pelayanan kesehatan Laboratorium Klinik menempati posisi yang penting dalam menegakkan diagnosis. Terdapat 5alasan penting yang menyebabkan pemeriksaan laboratorium diperlukan yaitu : skrining, diagnosis, pemantauan progresif penyakit, monitor pengobatan dan prognosis penyakit. Oleh karena itu setiap laboratorium harus dapat memberikan data hasil test yang cepat, tepat dan teliti. Untuk mendapatkan hasil yang akurat Laboratorium harus mengacu pada Good Laboratory Prosedure (GLP) yang meliputi tahapan Pra analitik, Analitik dan Pasca analitik (Direktorat Laboratorium Kesehatan Departemen Kesehatn RI, 2004).

Ada tiga tahapan penting dalam proses pengendalian mutu laboratorium, yaitu tahapan pra analitik, analitik dan pasca analitik. Pengendalian mutu pada umumnya hanya mengawasi tahap analitik dan pasca analitik yang lebih cenderung kepada urusan administrasi, sementara proses pra analitik kurang mendapat perhatian. Kesalahan yang terjadi pada proses pra analitik memberikan kontribusi sekitar $61 \%$ dari total kesalahan laboratorium, sementara $25 \%$ disebabkan oleh kesalahan analitik dan 14\% disebabkan oleh kesalahan pasca analitik. Terdapat dua kelompok proses pra analitik yaitu pra analitik ekstra laboratorium dan pra analitik intra laboratorium. Proses-proses tersebut meliputi persiapan pasien, pengambilan spesimen, pengiriman spesimen ke laboratorium, penanganan spesimen, dan penyimpanan specimen (Direktorat Laboratorium Kesehatan Departemen Kesehatn RI, 2004).

Persiapan pasien untuk pemeriksaan Laboartorium dimulaisaat dokter memutuskan pemeriksaan laboratorium bagi pasien. Dokter memberikan informasi mengenai tndakan apa yang akan dilakukan, manfaat dan persyaratan apa yang harus dilakukan oleh pasien. Pasien harus mendapatkan informasi yang jelas agar pasien tidak merasa takut atau memiliki persepsi yang keliru. Kondisi klinis pasien dan pemilihan test yang tepat penting untuk diperhatikan untuk mendapatkan hasil yang akurat, karena kondisi klinis pasien atau hasil pemilihan tes yang keliru dapat menghasilkan interprestasi hasil yang berbeda. Selain itu ketaatan ketaatan pasien akan instruksi yang telah diberikan oleh dokter atau paramedic sangat besar pengaruhnya terhadap hasil pemeriksaan laboratorium (Lestari, Chairlan, 2011).
Beberapa sumber kesalahan yang kurang terkontrol dari proses pra analitik yang dapat mempengaruhi keakuratan hasil pemeriksaan laboratorium, dan hal ini sulit untuk diidentifikasi oleh petugas laboratorium. Variabel ini misalnya adalah variable fisik pasien, seperti latihan fisik, puasa, diet, stress, efek posisi, gaya hidup Variabel tersbut mempunyai pengaruh yang kuat terhadap hasil pemeriksaan hematologi dan kimia klinik, sehingga kondisi ini harus diperhatikan sebelum pengambilan sampel (Joyce, 2007).

Beberapa parameter dalam pemeriksaan kimia klinik dipengaruhi oleh makanan, sehingga pengambilan sampel harus dilakukan setelah pasien berpuasa dalam jangka waktu tertentu, yaitu 8-10 jam. Jika kondisi ini tidak terpenuhi maka akan menyebabkan kondisi sampel yang kurang baik, misalnya sampel menjadi lipemik (Sacher, 2004).

Serum adalah bagian darah yang cair setelah darah membeku (Gandasoebrata 2013). Serum diperoleh setelah darah dibekukan selama 10-15 menit kemudian disentrifuge dengan kecepatan 1500 - 2000 rpm selama 10 menit. Cairan yang terbentuk akan berwarna kuning jernih, dan harus dipisahkan dari bekuan darah senelum dilakukan pemeriksaan.

Secara normal serum jernih denganwarna kuning muda, dalam keadaan tertentu dapat ditemukan serum yang keruh. Kekeruhan bervariasi mulai dari rungan sampai sangat keruh. Serum yang eruh ini dapat mengganggu pemeriksaan kimia darah (Dia Sys, 2019).

Serum lipemik adalah serum yang kekeruhan disebabkan oleh peningkatan konsentrasi lipoprotein yang dapat dilihat dengan mata (Gandasoebrata 2013 ) Penyebab kekeruhan adalah akumulasi dari partikel lipoprotein. Namun tidak semua jenis lipoprotein menyebabkan kekeruhan. Penyebab utama dari kekeruhan adalah kilomikron dengan ukuan $70-1000 \mathrm{~nm}$ yang merupakan partikel terbesar. Sementara akumulasi dari partikel yang kecil yaitu HDL (Hight Density Lipoprotein) dan LDL (Low Denxity ipoprotein) tidak meneyebabkan kekeruhan. Menurut Sacher dan Mc. Pherson 2004, kekeruhan pada serum mengindikasikan adanya peningkatan kadar VLDL (Very Low Density Lipoprotein) (Kee, 2013).

Terdapat tiga tingkatan kekeruhan pada serum yaitu : Peningkatan VLDL tanpa khilomikron yang signifikan (Uniform); peningkatan khilomikron dan VLDL ditandai dengan adanya krim diatas permukaan serum yang keruh dan peningkatan Khilomikron tanpa 
tanpa VLDL ditandai dengan krim diatas permuakaan serum yang jernih. (Sacher 2004). Selain khilomikron dan VLDL, kadar trigliserida dan kolesterol tinggi lebih dari 240 $\mathrm{mg} / \mathrm{dL}$ juga dapat menyebabkan kekeruhan pada serum (Baron, 2006).

Hampir semua pengukuran yang menggunakan spektrofotometri dengan penyerapan dan penghamburan cahaya terganggu dengan keadaan lipemik ini.

Kekruhan dapat berpengaruh terhadap penyerapan (absorbs) spektrofotometer pada semua panjang gelobang, sehingga dapat menyebabkan kesalahan pada nilai analisa (Piyophirapong dkk,2002). Lipoprotein dengan trigliserida konsentrasi tingi juga dapat mengganggu karena memiliki efek deplesi volume, dimana konsentrasi analit menurun karena lipoprotein menggantikan volume air. Dengan katalain volume yang tergantikan oleh lipoprotein terhitung sebagai konsentrasi analit (Baron, 2006).

Kualitas serum dapat dipengaruhi oleh makanan yang dimakan, diantaranya adalah glukosa, lemak dan kalsium. Oleh karena itu pengambilan sampel setelah makan dapat menjadi salah satu factor penyebab kesalahan pra analitik yang menghasilkan serum lipemik.

Beberapa methode dapat digunakan untuk menjernihkan serum lipemik, yaitu sentrifugasi, ekstraksi, pengenceran dan presipitasi. Standar emas untuk menjernihkan serum lipemik adalah sentrifugasi dengan alat ultrasentrifugasi. Namun cara ini memerlukan alat tambahan berupa centrifuge ultra yang mahal (WHO, 2002).

Metode lain untuk menjernihkan serum lipemik bisa dilakukan dengan method presipitasi menggunakan Poliethilen glikol ( PEG). Dimana PEG ini dapat mengikat lemak kemudian mengendapkannya sehingga serum menjadi jernih. PEG merupakan senyawa kimia yang tidak berbahaya dan murah. Menurut WHO penelitian mengungkapkan bahwa hasil pemeriksaan 20 unsur dalam serum tidak terpengaruh oleh presipitasi lipoprotein menggunakan PEG (WHO, 2002).

Polietilena glikol adalah polimer yang banyak digunakan dalam industri pangan, kosmetik, dan farmasi. Secara kimiawi, PEG merupakan sekelompok polimer sintetik yang larut air dan memiliki kesamaan struktur kimia berupa adanya gugus hidroksil primer pada ujung rantai polieter yang mengandung oksietilen. Rumus molekul $\mathrm{C}_{2 \mathrm{n}} \mathrm{H}_{4 \mathrm{n}+2} \mathrm{O}_{\mathrm{n}+1}$, massa molar $44 n+62$, larut dalam air, nama IUPAC poly (oxyethylene) atau poli (ethylene oxide) (Kuixiong, 1993).

Dalam bidang kesehatan PEG digunkan untuk melarutkan sediaan yang tidak larut dalam air. Berbagai jenis PEG dipasaran yang biasa digunakan dalam laboratorium.Bentuk PEG bisa berupa cairan maupun padatan tergantung dari Berat Molekul PEG itu sendiri. Sifat EPG yang sangat efektif dilingkungan yang berair dan membentuk dua fase sistem polimer yang berbeda. Ketika PEG melekat pada molekul polimer lain dapat mempengaruhi sifat kimia dan molekul lemak. PEG mengikat absobsi dan disolusi suatu lemak yang sukar larut dalam air. Beberapa penelitian telah membuktikan kegunaan PEG ini. Penelitian yang dilakukan oleh peneliti di Universitas Andalas menunjukkan bahwa penggunaan PEG $60008 \%$, dapat meningkatkan disolusi (Basel, 2009).

Pemeriksaan glukosa darah merupakan salah satu pemeriksaan kimia klinik yang banyak dilakukan seiring dengan meningkatnya kasus Diabetes Melitus di Indonesia. Pemeriksaan ini untuk darah sewaktu tidak melalui puasa, sehingga dapat ditemukan serum yang lipemik. Demikian juga untuk pemeriksaan enzim SGOT dan enzim SGPT tidak mengharuskan pasien puasa, sehingga jika pasien dengan kasus fatiliver bisa ditemukan serum lipemik.

Tujuan umum penelitian ini adalah untuk mengetahui pengaruh presipitasi mengunakan Poliethylen Glikol 6000. 8\% pada serum Lipemik terhadap hasil pemeriksaan glukosa darah, enzim SGOT dan SGPT.

\section{Metode}

Jenis penelitian kuantitatif desain studi eksperimen. Variabel terikat adalah presipitasi serum lipemik menggunakan Poliethylen Glikol 6000. 8\%, Variabel bebas adalah hasil pemeriksaan glukosa, SGOT dan SGPT. Analisa data menggunakan Independent Sampel $\mathrm{T}$ test. yaitu untuk menguji perbedaan mean hasil pemeriksaan Glukosa, SGOT dan SGPT serum lipemik sebelum dan sesudah di presipitasi dengan PEG.

Penelitian dilakukan di Laboratorium Kimia Klinik Jurusan Analis Kesehatan Poltekkes Tanjungkarang. Waktu penelitian pada bulan April sampai dengan November 2020. Subjek penelitian ini adalah spesimen serum lipemik yang diperoleh dari Laboratorium Patologi Klinik Rumah Sakit Umum Daerah Abdul Moeloek Lampung. 
Dilakukan 30 kali pengulangan untuk setiap parameter sebelum dan sesudah dipresipitasi.

Sampel terdiri dari serum gabungan atau pooled serum. Data diperoleh dengan cara (1) Mengambil serum lipemik di Rumah Sakit Umum Daerah Abdul Moeloek Provinsi Lampung. Setelah serum terkumpul lakukan pemeriksaan trigliserid untuk melihat seberapa besar serum tersebut mengalami lipemik, setelah itu dilakukan pemeriksaan kadar glukosa darah, SGOT dan SGPT. (2) Serum lipemik dipresipitasi dengan menggunakan Poliethylen Glikol 6000. 8\%, lalu lakukan pemeriksaan glukosa, SGOT dan SGPT.

\section{Hasil}

\section{Analisa Univariat}

Hasil pemeriksaan kadar glukosa,SGOT dan SGPT pada serum lipemik sebelum di presipitasi dengan PEG 6000 8\% dapat dilihat pada table 1 .

Tabel 1. Hasil pemeriksaan Glukosa, SGOT dan SGPT pada serum Lipemik sebelum dipresipitasi dengan PEG 6000 8\%

\begin{tabular}{lccc}
\hline & $\begin{array}{c}\text { Glukosa } \\
(\mathbf{m g} / \mathbf{d L})\end{array}$ & $\begin{array}{c}\text { SGOT } \\
(\mathbf{U} / \mathbf{L})\end{array}$ & $\begin{array}{c}\text { SGPT } \\
(\mathbf{U} / \mathbf{L})\end{array}$ \\
\hline Rata-rata & 119 & 48,42 & 153,84 \\
\hline Tertinggi & 136 & 68,3 & 168 \\
\hline Terendah & 108 & 36,8 & 144,7 \\
\hline
\end{tabular}

Dari table tersebut terlihat bahwa pada sampel lipemik hasil pemeriksaan Glukosa tertinggi adalah $136 \mathrm{mg} / \mathrm{dL}$, hasil ini berada pada nilai normal untuk glukosa sewaktu yaitu sampai dengan $140 \mathrm{mg} / \mathrm{dl}$.

Untuk Aktivitas enzim SGOT nilai tertinggi adalah $48,42 \mathrm{U} / \mathrm{L}$ yang juga berada sedikit diatas nilai normal yaitu $41 \mathrm{U} / \mathrm{L}$, sementara untuk akytivitas enzim SGPT tertinggi adalah 153,84 U/L ini berada lebih dari 3 kali niai normal yaitu $41 \mathrm{U} / \mathrm{L}$.

Tabel 2. Hasil pemeriksaan Glukosa, Enzim SGOT dan Enzim SGPT pada serum lipemik setelah dipresipitasi dengan PEG 6000 $8 \%$

\begin{tabular}{lccc}
\hline & $\begin{array}{c}\text { Glukosa } \\
(\mathbf{m g} / \mathbf{d L})\end{array}$ & $\begin{array}{c}\text { SGOT } \\
(\mathbf{U} / \mathbf{L})\end{array}$ & $\begin{array}{c}\text { SGPT } \\
(\mathbf{U} / \mathbf{L})\end{array}$ \\
\hline Rata-rata & 103,27 & 31,96 & 26,7 \\
\hline Tertinggi & 129 & 37,4 & 30 \\
\hline Terendah & 93 & 23,8 & 23,4 \\
\hline
\end{tabular}

Hasil setelah dipresipitasi dengan PEG 6000. $8 \%$ terlihat adanya penurunan baik untu Glukosa aktivitas, Enzim SGOT maupun Aktivitas Enzim SGPT. Penurunan tertinggi terihat pada Aktivitas Enzim SGPT, seperti yang terlihat pada table dibawah ini.

Tabel 3. Rerata penurunan setelah dipresipitasi dengan PEG 6000. 8\%

\begin{tabular}{lccc}
\hline & $\begin{array}{c}\text { Sebelum } \\
\text { Presipitasi }\end{array}$ & $\begin{array}{c}\text { Setelah } \\
\text { Presipitasi }\end{array}$ & $\begin{array}{c}\text { Persen } \\
\text { Penurunan }\end{array}$ \\
\hline Gulokosa & 119 & 103,7 & 13,22 \\
\hline SGOT & 48,42 & 31,96 & 33,99 \\
\hline SGPT & 153,84 & 26,7 & 82,64 \\
\hline
\end{tabular}

\section{Analisa Bivariat}

Analisa bivariat untuk mengetahui pengaruh variabel dapat dilakukan apabila data memenuhi persyaratan terdistribusi normal yaitu dengan cara uji normalitas data. Uji normalitas data dapat dilakukan menggunakan uji Kolmogorov-Smirnov dengan melihat nilai Asymp. Sig. Apabila nilai Asymp. Sig.>0,05, maka data terdistribusi data normal. Sedangkan apabila hasil Asymp. Sig. $<0,05$, maka data dinyatakan tidak terdistribusi normal. Hasil uji normalitas data menggunakan KolmogorovSmirnov menunjukkan bahwa hasil pengolahan data menghasilkan nilaip value untuk glukosa sebesar 0,149 , nilai $p$ value SGOT sebesar 0,157 dan nilai $p$ valueuntuk SGPT sebesar 0,200 artinya nila $\mathrm{p}$ value. $>0,05$, maka data dinyatakan terdistribusi normal.

\section{Hasil}

Tabel 4. Hasil Uji kadar Glukosa sebelum dan sesudah dipresipiatsi dengan PEG $600.8 \%$

\begin{tabular}{ccccc}
\hline Variabel & Mean & SD & SE & $\begin{array}{c}\text { P } \\
\text { value }\end{array}$ \\
\hline Kadar glukosa & 17,637 & 11.447 & 2.090 & 0,000 \\
\hline
\end{tabular}

Hasil uji kadar glukosa pada sampel lipemik sebelum dan sesudah dipresipitasi dengan PEG 6000.8\% didapatkan p value 0,000 lebih kecil dari tingkat kepercayaan $95 \%$ yaitu 0.005 , berarti ada perbedaan kadar glukosa darah sebelum dengan sesudah di presipitasi dengan PEG 6000.8\%.

Tabel 5. Hasil Uji Aktivitas Enzim SGOT sebelum dan sesudah dipresipiatsi dengan PEG $600.8 \%$

\begin{tabular}{lcccc}
\hline Variabel & Mean & SD & SE & $\begin{array}{c}\text { P } \\
\text { value }\end{array}$ \\
\hline SGOT & 16.45333 & 7.53094 & 1.37495 & 0.0000 \\
\hline
\end{tabular}


Hasil uji Aktivitas SGOT pada sampel Lipemik sebelum dan sesudah dipresipitasi dengan PEG $6000.8 \%$ p value 0,000 lebih kecil dari tingkat kepercayaan $95 \%$ yaitu 0.005 , berarti ada perbedaan aktivitas enzim SGOT sebelum dengan sesudah di presipitasi dengan PEG 6000.8\%.

Tabel 6. Hasil Uji Aktivitas Enzim SGPT sebelum dan sesudah dipresipiatsi dengan PEG $600.8 \%$

\begin{tabular}{lcccc}
\hline Variabel & Mean & SD & SE & $\begin{array}{c}\text { P } \\
\text { value }\end{array}$ \\
\hline SGOT & 127.83667 & 6.30913 & 1.15188 & 0.000
\end{tabular}

Hasil uji aktivitas SGPT pada sampel Lipemik sebelum dan sesudah dipresipitasi dengan PEG $6000.8 \%$ p value 0,000 lebih kecil dari tingkat kepercayaan 95\% yaitu 0.005 , berarti ada perbedaan aktivitas enzim SGPT sebelum dengan sesudah di presipitasi dengan PEG 6000.8\%.

\section{Pembahasan}

Hasil penelitian diatas menunjukkan bahwa terjadi penurunan kadar glukosa serum lipemik sebelum dipresipitasi dengan PEG $6000.8 \%$ dibandingkan dengan setelah dipresipitasi dengan PEG 6000.8\% yaitu dari rata-rata $119 \mathrm{mg} / \mathrm{dL}$ menjadi $103,27 \mathrm{mg} / \mathrm{dL}$ atau turun sebesar $13,22 \%$.

Pemeriksaan aktivitas enzim SGOT juga terjadi penurunan dari rata-rata aktivitas dari sebelum duoresipitasi dengan PEG 6000.8\% dibandingkan dengan stelah dipresipitasi dengan PEG $6000.8 \%$ yaitu dari 48,42 U/L menjadi 31,96 U/L atau turun sebesar 33, 99\%. Pemeriksaan aktivitas Enzim SGPT mengalami penurunan yang sangat besar dari sebelum dipresipitasi sebesar 153,84 U/L menjadi 26,7 U/L setelah dipresipitasi dengan PEG 6000.8\% atau menurun sebesar 82,64\%. Berdasarkan hasil diatas dapat diketahui bahwa pada sampel serum yang lipemik ditemukan hasil yang tinggi baik untuk glukosa, enzim SGOT maupun enzim SGPT. Kadar tinggi palsu ini tentu dapat menyebabkan kesalahan sebuah diagnosa.

Secara umum ada kesalahan yang terjadi pada proses pra analitik dalam melakukan pemeriksaan laboratorium, kesalahan ini sering tidak bisa dikontrol oleh petugas karna berhubungan dengan kondisi pasien dan kejujuran pasien. Keterangan yang diberikan oleh pasien dalam menanggapi instruksi dari dokter atau paramedis sangat tergantung pada kejujuran dan pemahaman pasien akan pentingnya sebuah proses. Yang pada ahirnya akan berimbas pada mutu dari sampel pasien itu sendiri. Misalnya pasien yang tidak berpuasa ketika akan dilakukan pemeriksaan biokimia, atau pasien yang obesitas. Sehingga serum pasien yang dihasilkan cenderung menjadi lipemik. Serum yang lipemik dapat berpengaruh terhadap hasil pemeriksaan kimia klinik yang sebagian besar reaksinya dibaca dengan menggunakan fotometer (Direktorat Laboratorium Kesehatan Departemen Kesehatn RI 2004).

Hal ini sesuai dengan penelitian Wheny Mufita (2017) yang melakukan penelitian tentang penggunaan PEG 600 8\% pada serum lipemik untuk pemeriksaan Kreatinin, dari penelitian tersebut diperoleh hasil ada perbedaan bermakna antara hasil sebelum dan sesudah dipresipitasidengan PEG 6000.8\%.

Hasil penelitian dari Beta Lutfi (2019) juga menunjukkan adanya penurunan yang bermakna pada kadar protein serum lipemik yang dipresipitasi dengan PEG 6000.8\% dengan yang tanpa PEG 6000.8\% (Lutfi, 2019).

Hasil pengujian serum Control yang diperlakukan sama dengan sampel diperoleh kadar $110,4 \mathrm{mg} / \mathrm{dL}$ sebelum dipresipitasi dan $110,2 \mathrm{mg} / \mathrm{dL}$ setelah dipresipitasi dengan menggunakan PEG $6000.8 \%$ hal ini menunjukkan bahwa kadar Glukosa dalam serum control tidak berubah dengan penambahan PEG $6000.8 \%$.

Hasil Uji statistic bivariat mengunakan Paired Sampel T-test untuk kadar glukosa diperoleh $\mathrm{p}$ value sebesar $0,000,(\mathrm{p}<0,05)$ yang beratti ada perbedaan bermakna antara sebelum dan sesudah perlakuan.

Demikian juga dengan hasil uji bivariate menggunaka Paired Sampel t-test untuk aktivitas enzim SGOT diperoleh hasil $\mathrm{p}$ value sebesar 0,000 $(\mathrm{p}<0,05)$ hasil yang sama juga diperoleh pada uji Paired sampel t-test untuk aktivitas enzim SGPT diperoleh $\mathrm{p}$ value sebesar $0,000(\mathrm{p}<0,05)$.

Dengan demikian dari ketiga pemeriksaan tersebut ketiga nya menunjukkan ada perbedaan yang significant antar sebelum dipresipitasi dengan PEG 6000.8\% dengan setelah dipresipitasi dengan PEG 6000.8\%.

Kekeruhan pada sampel lipemik dapat mengganggu reaksi serta penbacaan hasil reaksi kimia pada fotometer, lipemik menyebabkan sampel keruh yang akan meningkatkan penyerapan absorbance saat pembacaan dengan fotometer. 
Simpulan hasil pemerikaan Glukosa darah Enzim SGOT dan Enzim SGPT sebelum dipresipitasi dengan PEG $6000.8 \%$ adalah sebagai berikut (1) Glukosa rata-rata 119 $\mathrm{mg} / \mathrm{dL}$, kadar tertinggi $136 \mathrm{mg} / \mathrm{dL}$ kadar terendah $108 \mathrm{mg} / \mathrm{dL}$. (2) Enzim SGOT rata rata 48,43U/L tertinggi $63,8 \mathrm{u} / \mathrm{l}$ terendah 36,8 U/L (3) Enzim SGPT rata-rata 153,84U/L, tertinggi $168 \mathrm{U} / \mathrm{L}$ terendah 144,7 U/L. Hasil pemeriksaan Glukosa darah Enzim SGOT dan Enzim SGPT setelah dipresipitasi dengan PEG $6000.8 \%$ adalah sebagai berikut (1) Glukosa rata-rata $103 \mathrm{mg} / \mathrm{dL}$ tertinggi $129 \mathrm{mg} / \mathrm{dL}$ dan terendah $93 \mathrm{mg} / \mathrm{dL}$. (2) Enzim SGOT rata-rata 31,96 U/L,tertinggi 37,4 U/L dan terendah 23,8 U/L (3) Enzim SGPT rata-rata 26,7U/L tertinggi $30 \mathrm{U} / \mathrm{L}$ dan terendah $23,4 \mathrm{U} / \mathrm{L}$. (4) Ada perbedaan yang bermakna antara hasil Glukosa darah, Aktivitas Enzim SGOT dan Aktivitas Enzim SGPT sebelum dan sesudah presipitasi.

Saran untuk mengatasi kesalahan hasil pada pemeriksaan serum lipemik hendaknya dilakukan presipitasi terlebih dahulu menggunakan PEG 6000.8\%.

\section{Daftar Pustaka}

Beta lutfi Ayu nastiti 2019 .Perbedaan kadar Protein Total pada serum lipemik yang dipreparasi menggunkan Poliethylen Glikol $6000.8 \%$ dengan inkubasi pada suhu $4^{\circ} \mathrm{C}$, Suhu ruang dan tanpa inkubasi..Poltekkes Tanjungkarang 2019

Birkhäuser Basel. 2009.PEGylated Protein Drugs: Basic Science and Clinical Applications. ISBN 978-3-7643-86788.Page. 147

Direktorat Laboratorium Kesehatan Departemen Kesehatn RI, 2004 Pedoman praktek Laboratorium yang Benar (Good Laboratory Practice), Cetakan ke-3, Jakarta,

DiaSys.2019. .Diagnostic reagent for quantitative in Vitro determinan of glucose in serum or plasma on photometric systwma DiaSys Diagnostic Sysems GmbH Alte Strasse 9 '65558 Germany

DiaSys 2019. .Diagnostic reagent for quantitative in Vitro determinan of ASAT (GOT) in serum or plasma on photometric systwma DiaSys
Diagnostic Sysems GmbH Alte Strasse 9 ‘65558 Germany

DiaSys. 2019. .Diagnostic reagent for quantitative in Vitro determinan of ALAT (GPT) in serum or plasma on photometric systwma DiaSys Diagnostic Sysems GmbH Alte Strasse 9 '65558 Germany

DN.baron 2006.Kapita Selekta Patologi Klinik, Edisi 4 ,EGC Jakarta.

Ganda Soebrata.2103. Pemeriksaan Laboratorium Klinik, EGC Jakarta

Joyce LeFever Kee, 2007. Pedoman Pemeriksaan Laboratorium \& Diagnostik, EGC, Jakarta,

Kee, M 2013. Pedoman Pemeriksaan laboratorium dan Diagnostik Edisi 6, EGC Jakarta

Kuixiong Gao (1993). Polyethylene glycol as an embedment for microscopy and histochemistry. CRC Press. ISBN 978-08493-4323-0.Page.1-10

Lestari,Estu. Chairlan.2011. Pedoman Teknik Dasar Untuk Laboratorium Kesehatan. EGC,Jakarta.

Piyophirapong,S.M.D.,Wongtiraporn,W.M.D dkk 2010 Factitious Result in Clinical ChemistryTests Caused by Common Endogenous Interferents. Siriraj Medical Journal ,Volume 62 Number 4, july-August 2010

Sacher dan Mc Pherson,RA,2004,Tinjauan Klinis Hasil Pemeriksaan Laboratorium,Alih bahasa :Brahm U.P dan dewi wulandari, Jakarta EGC

Sari, Wheny Mufita. Hardisari,Ratih Ni. Sujono. 2017.Perbedaan kadar Kreatinin pada Y Serum Lipemik yang diolah dengan Polyethylene Glicol $6000 \quad 8 \%$ dan High Speed Sentrifugasi.Jurnal Kesehatan Volume 13 No 1.

WHO 2002 .Use of Anticoagulatn in Diagnostic Laboratory Investigation 